\title{
Microbial diversity in waters, sediments and microbial mats evaluated using fatty acid-based methods
}

\author{
A. Mrozik • A. Nowak $\cdot$ Z. Piotrowska-Seget
}

Received: 20 May 2013/Revised: 10 October 2013/Accepted: 17 November 2013/Published online: 10 December 2013

(C) The Author(s) 2013. This article is published with open access at Springerlink.com

\begin{abstract}
The review summarises recent advances towards a greater comprehensive assessment of microbial diversity in aquatic environments using the fatty acid methyl esters and phospholipid fatty acids approaches. These methods are commonly used in microbial ecology because they do not require the culturing of micro-organisms, are quantitative and reproducible and provide valuable information regarding the structure of entire microbial communities. Because some fatty acids are associated with taxonomic and functional groups of micro-organisms, they allow particular groups of micro-organisms to be distinguished. The integration of fatty acid-based methods with stable isotopes, RNA and DNA analyses enhances our knowledge of the role of micro-organisms in global nutrient cycles, functional activity and phylogenetic lineages within microbial communities. Additionally, the analysis of fatty acid profiles enables the shifts in the microbial diversity in pristine and contaminated environments to be monitored. The main objective of this review is to present the use of lipid-based approaches for the characterisation of microbial communities in water columns, sediments and biomats.
\end{abstract}

Keywords Biodiversity - Biomarker fatty acids . Community structure $\cdot$ Microbial biomass

\footnotetext{
A. Mrozik $(\bowtie) \cdot$ A. Nowak

Department of Biochemistry, Faculty of Biology and Environmental Protection, University of Silesia, Jagiellońska 28, 40-032 Katowice, Poland

e-mail: agnieszka.mrozik@us.edu.pl

Z. Piotrowska-Seget

Department of Microbiology, Faculty of Biology and Environmental Protection, University of Silesia, Jagiellońska 28, 40-032 Katowice, Poland
}

\section{Introduction}

Micro-organisms, including bacteria, archaea, protists and fungi, dominate waters, sediments and biomats in terms of their abundance and biomass. They represent a large and diverse pool of species and exhibit a vast array of metabolic functions. Some of them are key players in biogeochemical processes (Cotner and Biddanda 2002; Falkowski et al. 2008), participate in controlling water quality (Fonseca et al. 2001; Yu et al. 2009) and are responsible for the degradation of organic pollutants released in the environment (Männistö et al. 2001; Chinalia and Killham 2006; Slater et al. 2008). In the current context of global change, detailed knowledge about the microbial diversity, specific functions and ecology of micro-organisms that inhabit water columns, sediments and microbial biomats is needed (Duffy and Stachowicz 2006).

Over the last two decades, the field of microbial ecology has seen tremendous progress and a wide variety of methods that use signature lipid biomarkers (SLB) and nucleic acids have been developed for describing and characterising the functional and phylogenetic diversity of micro-organisms (Frostegård et al. 1993; Frostegård and Bååth 1996; Zinger et al. 2012). The advent of such approaches has enabled microbial communities to be studied with greater precision in comparison with traditional techniques. Conventional methods that rely on the culturing of micro-organisms do not describe entire communities because they allow only about 0.25 and $2 \%$ of total microbial population in freshwater and sea water to be isolated, respectively (Amann et al. 1995; Bernard et al. 2000).

Several unique classes of lipids, including steroids, diglycerides, triglycerides, respiratory quinines, poly- $\beta$-hydroxyalkanoate, phospholipid fatty acids, sphingolipids and 
hydroxyl fatty acids, can be used as signature lipid biomarkers (White and Ringelberg 1997). SLBs such as fatty acid methyl esters (FAMEs) and phospholipid fatty acids (PLFAs) are routinely used for the assessment of the microbial community structures of waters, sediments and biomats. PLFAs have a great potential to be biomarkers because the analysis of their pattern allows important attributes of microbial communities to be measured: viable biomass, nutritional/physiological status and microbial community structure (Zelles et al. 1994; Morgan and Winstanley 1997; White and Ringelberg 1997). The applicability of PLFAs for such studies results from their important features. Phospholipids are essential components of cell membranes, break down quickly after cell death, do not exist in storage lipids and anthropogenic contaminants and also have a high natural turnover rate (Findlay 1996; White et al. 1997). In addition, the sum of the fatty acids of a bacterial (15:0, 15:0 iso and anteiso, 16:0 iso, 16:1 19 ,

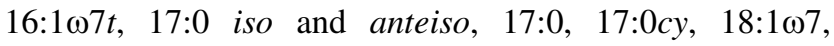

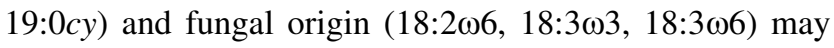
be used to calculate the biomass in environmental samples (Frostegård and Bååth 1996).

Fatty acid methyl esters analysis includes all of the saponifiable lipids that are present in a sample. The disadvantage of this method is the fact that FAMEs are derived from both living and dead cells and from all organisms that exist in environments that are tested. Despite these limitations, FAME analysis has been used to characterise microbial communities in aquifer environments and sediments in some studies (Elvert et al. 2003; Knief et al. 2003; Dias et al. 2009). Consequently, PLFA analysis is generally preferred for microbiological studies of such environments (Salomonová et al. 2003; Harji et al. 2010; Pratt et al. 2012).

In order to get more detailed information about microbial communities, lipid biomarkers are often used in combination with other measurements. It has been demonstrated that the use of the stable isotope probing (SIP) of RNA, DNA and PLFA biomarkers allows active members of microbial community to be identified and permits the phylogenetic lineages and functional activity of the microbial community structure to be established (Webster et al. 2006). Isotope ratios of PLFAs allow the organic matter sources that are utilised by bacteria to be studied (Boschker and Middelburg 2002) and the incorporation of fossil carbon into the microbial biomass to be investigated (Wakeham et al. 2006). PLFA analysis when used in conjunction with carbon isotope signature elucidates the carbon-cyclic pathways of bacteria and can indicate the potential carbon substrates for their metabolism (Boschker and Middelburg 2002; Holmer et al. 2004; Zhang et al. 2005; van den Meersche et al. 2009). In addition, PLFA analysis has been used to assess the response of microbial communities to physicochemical parameters of the environment and anthropogenic contaminants (Bittkau et al. 2004; Zhukova 2005).

The aims of this review are as follows: (1) an overview of lipid-based methods for analysing microbial communities in waters, sediments and microbial mats; (2) presentation of research results and (3) emphasising the need to combine lipid analyses with complementary methods for the characterisation of microbial communities.

\section{Microbial lipids}

Lipids are a structurally diverse class of molecules that have a very important, functional role in the metabolism of micro-organisms. Membrane lipids are divided into glycerophospholipids, sphingophospholipids, sphingo- and glyceroglycolipids according to backbone structure (Dowhan and Bogdanov 2002). In respect of chemical structure, phospholipids are amphiphatic molecules that contain both a polar head group and lipophilic region and generally have two acyl chains with 14-20 atoms of carbon. They are classified into ester-linked and ether-linked fatty acids. The first are main components of bacterial membranes, whereas the second ones are prevalent in the membranes of archaea (Green and Scow 2000; Lombard et al. 2012; Poerschmann et al. 2012).

Bacterial phospholipids typically contain saturated and monounsaturated fatty acids. Polyunsaturated fatty acids are rare and occur mostly in marine psychrophiles and cyanobacteria. The fatty acid structure and the portion of saturated, unsaturated, branched and cyclopropane fatty acids in individual phospholipids influence the fluidity and permeability of bacterial cytoplasmatic membranes (Dowhan and Bogdanov 2002; Denich et al. 2003; Li et al. 2007).

Lipid analysis from environmental samples consists of recovering lipids by extraction in organic solvents followed by analysis using high-resolution fused silica gas chromatography (Kennedy 1994; Kaur et al. 2005). For PLFA analysis, polar lipids have to be separated using silica solid-phase extraction columns with methanol. Next, phospholipids are converted into fatty acid methyl esters. An internal standard (mainly 19:0 fatty acid) is used to calculate individual fatty acid concentration. In the FAME approach, all of the isolated fatty acids that originated from all of the cell lipids are subjected to methanolysis and converted into methyl esters. The final products are identified using the computer program The Sherlock Microbial Identification System (MIDI, Inc., Newark, DE) by comparing their retention times with the retention times of bacterial acid standards. Unfortunately, this system only allows identification of fatty acids with 9-20 carbons in acyl chain. For the detection of longer fatty acids (up to 
30C) and the identification of fatty acid isomers, gas chromatography coupled with mass spectrometry (GC-MS) must be used (Hu et al. 2006; Dickson et al. 2009).

The PLFA profiles that are obtained from the environment can be analysed using two approaches. The first is based on the analysis of selected fatty acids that are known as biomarkers in order to detect the particular microorganisms or microbial group in samples being tested and indicates any changes within the groups (Frostegård and Bååth 1996). In the second approach, fatty acid patterns (fingerprinting) are subjected to multivariate statistical methods in order to simplify the data. The most commonly used method is principal component analysis (PCA) that visualises the differences in the fatty acid composition of samples being tested. Moreover, when the PCA is overlaid with the loadings of specific fatty acids, it is possible to discern the fatty acids that significantly influence the structure of microbial communities. Fingerprinted data can be used to determine the environmental factors that are strongly correlated with the microbial community structure. Ordination analyses such as redundancy analysis or canonical correspondence can be applied to do this (Green and Scow 2000).

The results of many studies have proven the usefulness of fatty acid-based methods in characterising the structure of soil and water microbial communities. However, this approach has some limitations since the interpretation of PLFAs that are indicative of different microbial groups is not straightforward and should be performed with caution. Not all PLFA peaks can be related to taxonomic groups, and signature fatty acids may be present in various microorganisms. For example, the PLFAs 17:0cy and 19:0cy, which are known to be indicators of gram-negative bacteria, are also present in some gram-positive bacteria

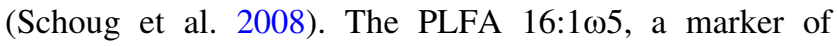
mycorrhizal fungi (Olsson 1999), was also found in bacteria (Nichols et al. 1986). Moreover, the fatty acid composition may be influenced by the physiology and nutritional status of micro-organisms. For example, an analysis of PLFA profiles showed that cyclopropyl fatty acids were synthesised by gram-positive bacteria from the genus Alicyclobacillus during peat heating (Ranneklev and Bååth 2003). It must be also underlined that fatty acidbased methods have a low level of taxonomic resolution. In order to overcome this problem, they are often combined with an analysis of nucleic acids isolated directly from the same samples.

\section{Microbial diversity in water columns}

Lipid-based methods have been used to study the biomass, activity and diversity of bacteria and archaea that exist in many types of aquatic systems (Sundh et al. 2005; Espinosa et al. 2009; Taipale et al. 2009). In comparison with solid environments, the use of PLFA/FAME analysis has problems that are connected with a low bacterial density in water, which has been estimated to be from $7 \times 10^{4}$ to $2.2 \times 10^{7}$ cells $\mathrm{mL}^{-1}$ (Männistö et al. 2001). For example, based on the phospholipid-derived ether lipid content, Mancuso et al. (1990) calculated the microbial biomass of a methanogenic population in the vertical layers in Ace Lake in Antarctica. They found that the number of bacteria depended on depth. Methanogens occurred at $17 \mathrm{~m}$ $\left(1 \times 10^{8}\right.$ cells $\left.\mathrm{L}^{-1}\right)$ and were dominant at $20 \mathrm{~m}\left(7.4 \times 10^{8}\right.$ cells $\left.\mathrm{L}^{-1}\right)$, and then population density decreased at $23 \mathrm{~m}$ $\left(1.3 \times 10^{8}\right.$ cells $\left.\mathrm{L}^{-1}\right)$. In other studies, Sundh et al. (2005) studied the abundance and activity of type I and II methane-oxidising bacteria (MOB) in the water column in three lakes Mårn, Illersjön and Lillsjön. The high concentration of $16: 1 \omega 8 c$ fatty acid indicated the dominance of MOB I, while low abundance of 18:1 $108 c$ showed a very low density of MOB II. Moreover, the analysis of PLFA profiles allowed them to observe a seasonal migration of microorganisms in all three lakes.

Lipid-based approaches also provide information about the distribution of bacteria and archaea in particular zones of reservoirs. For this purpose, apart from FAME and PLFA methods, the analysis of intact polar lipids (IPLs) may be used (Biddle et al. 2006; Lipp et al. 2008; Popendorf et al. 2011). Ertefai et al. (2008) examining the vertical distribution of bacteria in chemically distinct layers of a meromictic lake in eastern Massachusetts reported that bacterial IPLs constituted a major fraction of total IPLs in the epilimnion, metalimnion, hypolimnion and underlying sediment. This fraction included the following IPLs that are attributed to bacteria: diacyl phosphatidylethanolamine along with its methylated derivatives phosphatidylmethylethanolamine and phosphatidyldimethylethanolamine, phosphatidylglycerol, diphosphatidylglycerol, phosphatidylcholine and glycolipids monoglycosyldiacylglycerol and glycuronic acid dialkylglycerol. Bacteriohopanepolyols (BHPs) and slight negative inflections of the $\delta^{13} \mathrm{C}$ values of bacterial PLFAs in the metalimnion indicated a low contribution of methanotrophs among the metalimnetic bacteria. In the hypolimnion, dialkylglycerol-phosphatidylethanolamine, 17:0 PLFA and, additionally, $d s r A B$ genes suggested the presence of sulphate-reducing bacteria (SRB). Espinosa et al. (2009) found that the same SRB bacterial group was present not only in oxygen minimum zones but at all depths of the oceanic water column in Chile. Based on the PLFA profiling, they suggested that the vertical distribution of SRB is more homogeneous than was previously thought. In another study, PLFA analysis in conjunction with DNA techniques proved the vertical diversity of bacteria in the polyhumic Lake Mekkojarvi (Taipale et al. 2009). As was shown by the abundance of 
Table 1 Selected fatty acids as biomarkers of different genus, species or microbial groups detected in water columns

\begin{tabular}{|c|c|c|c|}
\hline $\begin{array}{l}\text { Genus, species, } \\
\text { microbial group }\end{array}$ & Biomarker & Study site & References \\
\hline Proteobacteria & $18: 1 \omega 7 c$ & $\begin{array}{l}\text { Crampton } \\
\text { Lake, } \\
\text { Wisconsin, } \\
\text { USA }\end{array}$ & $\begin{array}{l}\text { Pace et al. } \\
\text { (2007) }\end{array}$ \\
\hline $\begin{array}{l}\text { Anaerobic metal } \\
\text { reducing } \\
\text { bacteria }\end{array}$ & $\begin{array}{l}\text { Branched } \\
\text { monoenoic and } \\
\text { midchain } \\
\text { branched } \\
\text { saturated PLFA }\end{array}$ & $\begin{array}{l}\text { Lake Lucero, } \\
\text { Southern } \\
\text { New } \\
\text { Mexico }\end{array}$ & $\begin{array}{l}\text { Schulze- } \\
\text { Makuch } \\
\text { (2002) }\end{array}$ \\
\hline $\begin{array}{l}\text { Polar gas- } \\
\text { vacuolated } \\
\text { bacterium: } \\
\text { Psychromonas } \\
\text { ingrahamii }\end{array}$ & $16: 1 \omega 7 c, 16: 0$ & $\begin{array}{l}\text { Point } \\
\text { Barrow, } \\
\text { Alaska, } \\
\text { USA }\end{array}$ & $\begin{array}{l}\text { Auman et al. } \\
\text { (2006) }\end{array}$ \\
\hline $\begin{array}{l}\text { Methanotrophic } \\
\text { bacteria type I }\end{array}$ & $\begin{array}{c}16: 1 \omega 5 c \\
16: 1 \omega 5 t \\
16: 1 \omega 8 c\end{array}$ & $\begin{array}{l}\text { Gotland } \\
\text { Deep, } \\
\text { Baltic Sea }\end{array}$ & $\begin{array}{l}\text { Berndmeyer } \\
\text { et al. } \\
(2013)\end{array}$ \\
\hline Actinobacteria & $\begin{array}{l}\text { iso and anteiso- } \\
\text { branched } \\
\text { PLFAs }\end{array}$ & $\begin{array}{l}\text { Mekkojärvi } \\
\text { Lake, } \\
\text { Finland }\end{array}$ & $\begin{array}{l}\text { Taipale et al. } \\
\text { (2009) }\end{array}$ \\
\hline $\begin{array}{l}\text { Desulfobacter, } \\
\text { Desulfovibrio, } \\
\text { Desulfolobus }\end{array}$ & $\begin{array}{l}\text { Branched 17:1, } \\
\text { 16:0 10Me, } \\
17: 1\end{array}$ & $\begin{array}{l}\text { Mekkojärvi } \\
\text { Lake, } \\
\text { Finland }\end{array}$ & $\begin{array}{l}\text { Taipale et al. } \\
\text { (2009) }\end{array}$ \\
\hline Chlorobium & $\begin{array}{l}\text { 14:0, 16:0, 16:1 } \\
\text { (constitute } \\
90 \% \text { of all } \\
\text { PLFAs) }\end{array}$ & $\begin{array}{l}\text { Mekkojärvi } \\
\text { Lake, } \\
\text { Finland }\end{array}$ & $\begin{array}{l}\text { Taipale et al. } \\
\text { (2009) }\end{array}$ \\
\hline
\end{tabular}

18:1 107 , gram-negative bacteria dominated in epilimnetic bacterioplankton, whereas Actinobacteria constituted only a minor fraction of microbial population. It was also reported that biomass of the MOB I type, expressed as amount of $16: 1 \omega 8 c$ and $16: 1 \omega 5 t$, was the highest in the $0-0.6-$ and $1.2-1.8-\mathrm{m}$ water layers. Due to the abundance of 14:0, they stated that Chlorobium sp. dominated the anoxic layer where the biomass of microbial PLFAs was six times higher than in the oxic surface layer.

Phospholipid fatty acid analysis has also been used to determine whether local primary production or external carbon inputs support bacterial growth in an area that is studied. Pace et al. (2007) tested the importance of allochthonous carbon to consumers by adding $\mathrm{H}^{13} \mathrm{CO}_{3}$ to Crampton Lake in the USA. Analysis of the PLFA profiles revealed that in addition to Cytophaga-Flavobacteria, diatoms, green algae and dinoflagellates were present in the pelagic zone, which was indicated by biomarker fatty acids

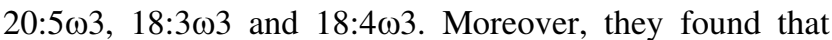
autochthonous carbon was the dominant source for grampositive bacteria, zooplankton biomass and Chaoborus spp., while gram-negative bacteria incorporated significant quantities of carbon from terrestrial sources. Selected fatty acid biomarkers that indicate a different genus, species or microbial group in waters are shown in Table 1 .

Microbial diversity in sediments

Although the subsurface environment represents a substantial part of the biosphere, little is known about the procaryotic distribution and community structures in this habitat. This knowledge is very important in respect of the major role of micro-organisms in carbon cycling and global geochemistry (Parkes et al. 1994). It has been estimated that the number of procaryotic cells in the largely unexplored sediments is about $8-35 \times 10^{29}$, which represents $10-30 \%$ of the total biomass on earth (Whitman et al. 1998); however, their total activity is significantly lower as compared to the surface sediments (D'Hondt et al. 2002). Due to complex matrix of organic materials and the overall low biomass, it is a real challenge to investigate the distribution, physiology and role of micro-organisms in nutrient turnover in the marine subsurface. The use of fatty acid biomarkers has revealed the presence of unique microbial communities in these habitats (Inagaki et al. 2006; Lipp and Hinrichs 2009).

An analysis of IPLs in subsurface sediments during the Ocean Drilling Program Leg 201 indicated that the active portion of the microbial community was dominated by archaea (Biddle et al. 2006). These results were supported by study of Lipp et al. (2008), who found that the major archaeal lipids, such as the diglycosidic derivatives of archaeol and glycerol dibiphytanyl glycerol tetraether lipids, dominated sediments that were deeper than $0.1 \mathrm{~m}$ below the sea floor. Similarly, on the basis of IPL profiles, the dominance of archaeal ether lipids in deeply buried sediments from equatorial Pacific in Peru has been reported by Lipp and Hinrichs (2009). They also found that bacterial phospholipids were present only in surface sediments. This observation was confirmed by Molari et al. (2012), who studied the subsurface coastal sediments in the Manfredonia Gulf using catalysed reporter deposition fluorescence in situ hybridisation (CARD-FISH). They showed that bacteria dominated the first $11 \mathrm{~cm}$ below the sediment surface, and then the community significantly moved towards archaeal dominance at increasing depths.

In the 1980s, PLFA analysis started to be used to examine the microbial community structure in estuarine and marine sediments. David White was the first who used PLFAs for the description of the structure of microbial communities in sediments (White 1983). Next, Rajendran et al. (1992) distinguished six clusters of PLFA profiles based on the relative proportions of PLFAs, thus proving the distinctive differences between sampling points within the sediment of bays (Hiroshima and Aki Nada). Moreover, they found that the microbial community structure of the 
areas showed very low percentages of the polyunsaturated fatty acids that are characteristic of Eukaryota and high percentages of fatty acids that are typical for bacteria. Similarly, the dominance of bacteria at both depositional and non-depositional sites in the North Sea was reported by Stoeck et al. (2002). An analysis of PLFA profiles showed a high abundance of Cytophaga-Flavobacterium-Bacteroides and Actinomycetes, bacterial groups that are involved in the degradation of complex macromolecules, at depositional sites as compared to other sites. Based on the abundance of trans isomers, they stated that microbial communities at non-depositional sites were exposed to higher physiological stress than those from the sediments of depositional areas. The PLFA approach combined with the characterisation of small-subunit rRNA genes indicated a shift in the bacterial community that coincided with the depth of the sediments of the saline lake in China (Dong et al. 2006). The authors found that monoenoic PLFAs, which are characteristic of the Proteobacteria, were present in all samples and comprised from 15 to $33 \%$ of total PLFAs while the content of terminal branched saturated fatty acids, which are indicative of anaerobic gram-negative bacteria and Firmicutes, ranged from 5 to $14 \%$ of total PLFAs. Moreover, the decrease in monoenoic PLFAs was correlated with an increase in branched PLFA content with increased depths. These observations proved that Firmicutes dominated the bottom, which was also in accordance with the oxygen gradient in the pore water in the sediment. Similarly, Baniulyte et al. (2009) combined PLFA and terminal restriction fragment length polymorphism (TRFLP) of $16 \mathrm{~S}$ rDNA gene analyses to determine any changes in the microbial community composition in sediment from Illinois River applied to soil surface. The analysis of their data indicated a significant shift in the bacterial community that resulted from the relative increase in fungi $(18: 1 \omega 9 c$ and $18: 1 \omega 6,9 c)$, actinomycetes (18:0 $10 \mathrm{Me})$ and gram-positive bacteria (15:0 iso, 16:0 iso and 16:0 10Me) and a decrease in gram-negative bacteria $(16: 1 \omega 7 c, 17: 0 c y, 18: 1 \omega 7 c, 19: 0 c y)$. Additionally, clone library analysis revealed an increase in the relative percentage of Proteobacteria, Gammatimonadetes and Bacteroidetes and a simultaneous decrease in Acidobacteria, Spirochaetes and Planctomycetes. In other studies, PLFA analysis supported by epifluorescent microscopy was used by Kaštovská et al. (2007) to study the microbial ecology of subglacial sediments in the Svalbard glaciers. The combination of these methods allowed the detection of cyanobacteria and microalgae in four sediments; however, the diversity of micro-organisms was low. They found no signature fatty acids for eucaryota with only one exception for fungal fatty acids. The percentage of signature PLFAs $18: 3 \omega 3$ and $20: 3 \omega 3$ showed that cyanobacteria made up the highest fraction of the microbial community as their contribution in PLFA profiles constituted from 28.7 to $81 \%$ of the total PLFAs.

The fact that specific lipids and/or fatty acids reflect the taxonomic or functional groups of micro-organisms has been used to detect ammonia-oxidising (AOB) (Saenz et al. 2012), sulphate-reducing bacteria (SRB) (Elvert et al. 2003) and methanotrophs in sediments (Costello et al. 2002; Mills et al. 2010). For example, Saenz et al. (2012) investigated the presence of anaerobic $\mathrm{AOB}$ in the Waquoit Bay subterranean estuary using two types of ladderane lipids. The first included an intact phospholipid (PC monoalkylether) that rapidly degraded after cell death, and the second were ladderane fatty acids that are likely to persist for thousands of years following cell death. The presence of ladderane phospholipid is thought to be an indicator of viable or recently deceased cells, whereas ladderane fatty acids provide insight into the historical distribution of bacteria and their temporal stability. From the distribution of sediment-bound ladderane phospholipid, they demonstrated that viable anammox bacteria were present in three redox transition zones within the subterranean estuary. In turn, the distribution of ladderane fatty acids indicated that the vertical distribution of anammox bacteria has been constant over the time period during which these lipids accumulated. In other studies, FAME analysis of specific membrane fatty acids combined with a microscopic examination using fluorescence in situ hybridisation (FISH) was used to determine the presence and activity of SRBs that are involved in the anaerobic oxidation of methane $(\mathrm{AOM})$ in the sediment core (Elvert et al. 2003). The results indicated that monounsaturated fatty acids $16: 1 \omega 7 t$ and $16: 1 \omega 5 c$ dominated and accounted for about $50 \%$ of the total fatty acids present in samples tested. Interestingly, FAME profiles contained a high amount of cyclic unusual fatty acid 17:0cy $\omega 5,6$ that was proposed by authors as chemotaxonomic markers of the AOM-dependent Desulfosarcina/Desulfococcus species. An assessment of the natural abundance of $\delta^{13} \mathrm{C}$ and ${ }^{14} \mathrm{C}$ values of microbial membrane PLFAs allowed Mills et al. (2010) to detect methanotrophs type II in the sediments and granitic groundwater in Japan. The analysis of PLFA profiles showed that $18: 1 \omega 8 c$, a biomarker for this microbial group, comprised 3 and $18 \%$ of the total PLFAs in anoxic sediments and granitic waters, respectively. These results were unexpected since type II methanotrophs are considered to be obligate aerobes. In another study, Knief et al. (2003) demonstrated the activity of iron-oxidising bacteria through an analysis of the incorporation label into FAMEs that were isolated from sediment taken from an acid mining lake characterised by a low $\mathrm{pH}$ and a high sulphate concentration. The presence of $16: 1 \omega 7 c$ and 16:0 11Me fatty acids in combination with 16:0 with the strongest labelling indicated that Leptospirillum ferrooxidans was present in 
the sediment. The fatty acid $16: 1 \omega 7 c$, which is typical for these bacteria, was a minor component in FAME profiles although it was strongly labelled. This indicated that $L$. ferrooxidans made up only a small percentage of the bacterial population but that it was the primary producer in the ecosystem. Weak labelling of 19:0 $11,12 c y$ indicated the presence of other chemolithoautotrophic or heterotrophic organisms, such as bacteria from the genera Acidithiobacillus or Acidiphilium.

Fatty acid-based methods have also been used to determine the impact of various pollutants on the microbial community structure. Rajendran et al. (1992) noted the predominance of anaerobic and gram-positive bacteria, which was revealed by high proportions of branched PLFAs at sites that were highly polluted with heavy metals and various organic chemicals, while aerobic procaryotes and eucaryotes, as evidenced by large amounts of monounsaturated PLFAs, dominated other less contaminated sites. Chinalia and Killham (2006) used PLFA and denaturing gradient gel electrophoresis (DGGE) profiling to assess alterations in microbial communities in the 2,4dichlorophenoxyacetic acid (2,4-D)-contaminated river sediments of northeast Scotland. PCA revealed that 2,4-D caused changes in PLFA profiles that were more pronounced for non-bacterial fatty acids than for signature bacterial PLFAs. They suggested that in the first sediment, the main variation in the microbial population was connected with long-chain PLFAs that are characteristic of dinoflagellates and other planktonic organisms, whereas in the second one, the shift in PLFA profiles depended on cyanobacteria and flagellate biomarkers. In addition, they observed that the abundance of fatty acids 16:1 $\omega 9,16: 1 \omega 7$,

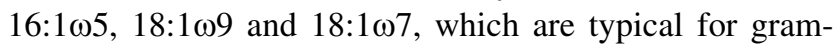
negative bacteria, varied in samples that were tested and resulted from different doses of 2,4-D. Similarly, Widenfalk et al. (2008) observed that exposure to the pesticides captan, glyphosate, isoproturon and pirimicarb had only a slight effect on the bacterial PLFA profiles in the lake sediments of Lake Erken. Signature lipid biomarkers were also used by Varadhan et al. (2011) for the detection of changes within microbial communities in sediments contaminated with polychlorinated biphenyls (PCBs) and exposed to iron. They observed the dominance of $\mathrm{De}$ halococcoides species in the sediments exposed to a lower dosage of iron $(0.01 \mathrm{~g}$ iron per $\mathrm{g}$ of dry sediment every 6 months), whereas in sediments with a higher dosage of iron $(0.1 \mathrm{~g}$ iron per $\mathrm{g}$ of dry sediment every 3 months) dominated Geobacteraceae and SRB bacteria. In the PAHcontaminated sediments, Pratt et al. (2012) observed that apart from non-specific fatty acids, microbial biomarkers that are characteristic of SRB and other anaerobic bacteria dominated all of the samples. The obtained data indicated that PAH contamination did not markedly influence the distribution of PLFA markers with exception of samples taken at a greater depth.

Phospholipid fatty acid analysis also allows the sources of organic matter (OM) in aquifers to be monitored. OM originates from various terrestrial and marine sources such as primary production by phytoplankton and benthic microalgae, higher plants, river run-off, municipal sewage and industrial contamination in estuarine and coastal sediments (Hedges et al. 1997). A technique that involves the incorporation of stable or radiocarbon isotopes into microbial PLFAs was used to identify and understand the carbon sources of organic matter that support bacterial production (Tolosa et al. 2003; Druffel et al. 2010). Using this approach, Harji et al. (2010) revealed that terrestrial carbon accounted for $37-100 \%$ of total organic carbon in sediments of the harbour in Visakhapatnam. Based on the fatty acid composition and $\delta^{13} \mathrm{C}$ fatty acids, it has been found that bacteria within the sediments were dependent on the marine source of organic matter and mainly utilised a labile pool of organic matter that was derived from algae $(\mathrm{Hu}$ et al. 2006). In turn, Wakeham et al. (2006) calculated that $6-10 \%$ of the carbon in bacterial PLFAs could have been derived from petroleum residues, which suggested that even weathered petroleum might contain components with sufficient viability to be a carbon source for microbial biomass production in marsh sediments. Examples of the fatty acid biomarkers detected in the sediment samples are presented in Table 2.

\section{Microbial diversity in biomats}

Microbial mats are stratified microbial communities that develop in the environments that are established at the water and solid interfaces. In studies on biomats, special attention is focused on the distribution and interaction between micro-organisms, the colonised surface and the surrounding environment (Stolz 2000). For example, Dijkman et al. (2010) using PLFA approach revealed changes in the composition and heterogeneity of the microbial community in various costal microbial mats on the beaches of the North Sea. The ratio of $16: 1 \omega 7 c$ over 16:0, fatty acids $18: 1 \omega 9 c, 18: 1 \omega 7 c, 18: 3 \omega 6$ and $18: 3 \omega 3$ indicated the presence of cyanobacteria at the tested sites. In turn, $18: 4 \omega 3$ pointed to the presence of diatoms. In another study, Villanueva et al. (2007) observed the daily migrations of micro-organisms in an intertidal hypersaline microbial mat in France. They reported that the total PLFAs that indicated the maximum viable biomass were the highest at the top of the mat in the morning hours, while in the afternoon the highest volume was found underneath the uppermost layers. As indicated by the ratio of cyclopropyl fatty acids to monoenoic PLFAs, the microbial growth was the highest at the top in the morning hours and 
Table 2 Biomarkers of different genus, species or microbial groups detected in sediments

\begin{tabular}{|c|c|c|c|}
\hline Genus, species, microbial group & Biomarker & Study site & References \\
\hline Microeucaryotes & Polyunsaturated fatty acids & Nakhodka Bay, Vostok Bay, Sea of Japan, Russia & Zhukova (2005) \\
\hline Aerobic procaryotes and eucaryotes & $16: 1,17: 1,18: 1,18: 2$ & Nakhodka Bay, Vostok Bay, Sea of Japan, Russia & Zhukova (2005) \\
\hline $\begin{array}{l}\text { Aerobic heterotrophic } \\
\text { microeucaryotes }\end{array}$ & $18: 1 \omega 9,18: 2 \omega 6$ & Little Scioto River, Marion, Ohio, USA & $\begin{array}{l}\text { Langworthy et al. } \\
\text { (2002) }\end{array}$ \\
\hline Proteobacteria & Monoenoic PLFA & Qinghai Lake, China & Dong et al. (2006) \\
\hline Beggiatoa/Thioploca & $16: 1 \omega 7 c, 18: 1 \omega 7 c$ & Gulf of Mexico, USA & Li et al. (2007) \\
\hline Sulphate-reducing bacteria & $\begin{array}{l}\text { 15:0 anteiso, 15:0 iso, } \\
16: 010 \mathrm{Me}\end{array}$ & Gulf of Mexico, USA & Li et al. (2007) \\
\hline $\begin{array}{l}\text { Sulphate-reducing and other } \\
\text { anaerobic bacteria }\end{array}$ & $\begin{array}{l}\text { 17:0, 17:0iso, 17:0 anteiso, } \\
17: 0 c y, 19: 0 c y, 16: 010 \mathrm{Me}\end{array}$ & Nakhodka Bay, Vostok Bay, Sea of Japan, Russia & Zhukova (2005) \\
\hline Desulfolobus & $\begin{array}{l}17: 1 \omega 6 c \text { (high amounts, up } \\
\text { to } 60 \% \text { ) }\end{array}$ & Hydrate Ridge NE Pacific & Elvert et al. (2003) \\
\hline Desulfosarcina/Desulfococcus & $16: 1 \omega 5 c, 17: 0 \omega 5,6 c y$ & Hydrate Ridge NE Pacific & Elvert et al. (2003) \\
\hline Cyanobacteria & $18: 3 \omega 3,20: 3 \omega 3$ & $\begin{array}{l}\text { Werenskioldbreen and Torellbreen glaciers, } \\
\text { Spitsbergen, Svalbard }\end{array}$ & $\begin{array}{l}\text { Kaštovská et al. } \\
\text { (2007) }\end{array}$ \\
\hline Actinomycetes & 18:0 10Me & Lower Peoria Lake, USA & $\begin{array}{l}\text { Baniulyte et al. } \\
\text { (2009) }\end{array}$ \\
\hline Methanotrophs type I & $16: 1 \omega 8$ & Lake Washington, USA & $\begin{array}{l}\text { Costello et al. } \\
\text { (2002) }\end{array}$ \\
\hline Methanotrophs type II & $18: 1 \omega 8$ & Lake Washington, USA & $\begin{array}{l}\text { Costello et al. } \\
\text { (2002) }\end{array}$ \\
\hline Acidithiobacillus ferrooxidans & $\begin{array}{l}16: 1 \omega 5 c, 17: 1 \omega 8 c \\
17: 1 \omega 7 c \text { anteiso }\end{array}$ & Lake (ML) 111, Lusatian region, Germany & $\begin{array}{l}\text { Poerschmann et al. } \\
\text { (2012) }\end{array}$ \\
\hline Thiobacillus & 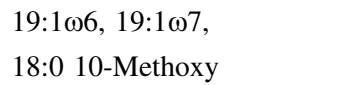 & Lake (ML) 111, Lusatian region, Germany & $\begin{array}{l}\text { Poerschmann et al. } \\
\text { (2012) }\end{array}$ \\
\hline
\end{tabular}

Table 3 Fatty acid biomarkers of genus and microbial groups used for assessment of biodiversity of microbial mats

\begin{tabular}{|c|c|c|c|}
\hline Genus, microbial group & Biomarker & Study site & References \\
\hline Cyanobacteria & $16: 1 \omega 7,18: 1 \omega 9$ & Kiritimati, Republic of Kiribati & Bühring et al. (2009) \\
\hline Microcystis & $\begin{array}{c}18: 3 \omega 3,18: 3 \omega 6, \\
18: 2 \omega 6 c \\
18: 1 \omega 9 c\end{array}$ & Lake Taihu, China & Kluijver et al. (2012) \\
\hline Synechococcus sp. & 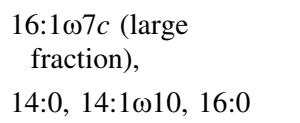 & Schiermonnikoog Island, The Netherlands & Dijkman et al. (2010) \\
\hline $\begin{array}{l}\text { Microcoleus, Anabaena, Aphanizomenon, } \\
\text { Nostoc }\end{array}$ & $\begin{array}{l}18: 3 \omega 3,18: 2 \omega 6 c \\
16: 0,16: 1 \omega 7 c\end{array}$ & Schiermonnikoog Island, The Netherlands & Dijkman et al. (2010) \\
\hline Calothrix, Nodularia & $\begin{array}{l}18: 4 \omega 3,18: 3 \omega 3, \\
18: 2 \omega 6 c \\
16: 0,16: 1 \omega 7 c\end{array}$ & Schiermonnikoog Island, The Netherlands & Dijkman et al. (2010) \\
\hline Sulphur-oxidising bacteria & $\begin{array}{l}16: 1 \omega 7 c / t, 18: 1 \omega 7 c \\
16: 0\end{array}$ & Gas Hydrates in the Gulf of Mexico & Zhang et al. (2005) \\
\hline Thermus & $15: 0$ iso, $16: 0$ iso, $17: 0$ & $\begin{array}{l}\text { Yellowstone National Park hot Springs, } \\
\text { USA }\end{array}$ & Osburn et al. (2011) \\
\hline Methanotrophs type I & $16: 1 \omega 6,16: 1 \omega 8$ & Coal Oil Point seep field, California, USA & $\begin{array}{l}\text { Ding and Valentine } \\
\text { (2008) }\end{array}$ \\
\hline
\end{tabular}

decreased with depth, while in the afternoon the slowest growth was detected at the top and the middle of the mat. Moreover, they revealed that gram-negative bacteria (indicated by the monoenoic PLFAs) dominated in the morning, while gram-positive bacteria (detected as branched saturated FAs) were more abundant in the middle and 
the deepest layers of the biomat. The dominance of cyanobacteria in another hypersaline mat was observed by Bühring et al. (2009). Cyanobacterial marker fatty acids

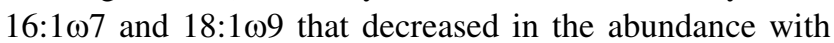
depth occurred in all of the layers that were tested. In addition to cyanobacteria, they also found the following groups of micro-organisms-PSB that dominated the middle layers, SRB that were present at all depths and archaea, possibly methanogens, that were also present in all layers. The same bacterial groups with dominance of cyanobacteria in the high-salinity mats of Abu Dhabi were also reported by Scherf and Rullkötter (2009).

Lipid biomarker analysis integrated at a ratio of ${ }^{13} \mathrm{C} /{ }^{12} \mathrm{C}$ and 16S rRNA gene sequencing was used to demonstrate the composition and metabolic activity of Beggiatoa mats in sulphide-rich marine sediments in the Gulf of Mexico (Zhang et al. 2005). The distribution of $16: 1 \omega 7 c$ (53.6\%), $16: 1 \omega 7 t(12.8 \%), 16: 0(8.3 \%)$ and $18: 1 \omega 7 c(16.6 \%)$ in the PLFA profiles suggested the dominance of sulphur-oxidising bacteria including Beggiatoa, Thioploca and Thiomargarita. Moreover, they also found other fatty acids (15:0 iso, 15:0 anteiso, 17:0 iso and 17:0 anteiso) that are characteristic of these bacteria, although each of them comprised less than $1 \%$ of the total PLFAs. The carbon isotope composition of the biomass and lipid biomarkers indicated that Beggiatoa grew on crude oil or its intermediates from microbial degradation and did not use methane as a carbon substrate. The selected fatty acid biomarkers that were detected in the microbial mats are presented in Table 3.

\section{Conclusion}

Fatty acid-based methods offer quick and inexpensive ways of assaying the biomass and composition of microbial communities in aquatic environments. The advantages of these methods are related to the fact that lipids are extracted directly from an environmental sample and are both quantitative and highly reproducible. Many studies proved their applicability for measurements of the biodiversity and distribution of bacteria and archaea in waters, sediments and mats. Moreover, stable isotope-labelled fatty acids or lipids can be used to assess the external carbon inputs on bacterial growth. Despite these advantages, fatty acid-based techniques have limitations. The analysis of microbial diversity can be not accurate and precise since most fatty acids are present in many taxonomic microbial groups. Therefore, fatty acid profiling provides a low taxonomic resolution and is mainly used for the detection of selected microbial groups (cyanobacteria, SRB, MOB I and MOB II). Due to these limitations, there is a need to combine fatty acid-based methods with molecular techniques that require nucleic acid extraction and further analysis. Because these methods have different strengths and weaknesses, they complement one another.

Acknowledgments This work was supported by the UE Innovate Economy Operational Programme, "Research and development of modern technologies", Project "An integrated system supporting the management and protection of the water reservoir", No: POIG 01.01.02-24-078/09.

Open Access This article is distributed under the terms of the Creative Commons Attribution License which permits any use, distribution, and reproduction in any medium, provided the original author(s) and the source are credited.

\section{References}

Amann RI, Ludwig W, Schleifer KH (1995) Phylogenetic identification and in situ detection of individual microbial cells without cultivation. Microbiol Rev 59:143-169

Auman AJ, Breezee JL, Gosink JJ, Kampfer P, Staley JT (2006) Psychromonas ingrahamii sp. Nov., a novel gas vacuolated, psychrophilic bacterium isolated from Arctic polar sea ice. Int J Syst Evol Microbiol 56:1001-1007

Baniulyte D, Favila E, Kelly JJ (2009) Shifts in microbial community composition following surface application of dredged river sediments. Microb Ecol 57:160-169

Bernard L, Schäfer H, Joux F, Courties C, Muyzer G, Lebaron P (2000) Genetic diversity of total, active and culturable marine bacteria in coastal seawater. Aquat Microb Ecol 23:1-11

Berndmeyer C, Thiel V, Schmale O, Blumenberg M (2013) Biomarkers for aerobic methanotrophy in the water column of the stratified Gotland Deep (Baltic Sea). Org Geochem 55:103-111

Biddle JF, Lipp JS, Lever MA, Lloyd KG, Srrrensen KB, Erson R, Fredricks HF, Elvert M, Kelly TJ, Schrag DP, Sogin ML, Brenchley JE, Teske A, House CH, Hinrichs KU (2006) Heterotrophic archaea dominate sedimentary subsurface ecosystems off Peru. Proc Natl Acad Sci USA 103:3846-3851

Bittkau A, Geyer R, Bhatt M, Schlosser D (2004) Enhancement of the biodegradability of aromatic groundwater contaminants. Toxicology 205:201-210

Boschker HTS, Middelburg JJ (2002) Stable isotopes and biomarkers in microbial ecology. FEMS Microb Ecol 40:85-95

Bühring SI, Smittenberg RH, Sachse D, Lipp JS, Golubic S, Sachs JP, Hinrichs KU, Summons RE (2009) A hypersaline microbial mat from the Pacific Atoll Kiritimati: insights into composition and carbon fixation using biomarker analyses and a ${ }^{13} \mathrm{C}$-labeling approach. Geobiology 7:1-16

Chinalia FA, Killham KS (2006) 2,4-Dichlorophenoxyacetic acid $(2,4-\mathrm{D})$ biodegradation in river sediments of Northeast-Scotland and its effect on the microbial communities (PLFA and DGGE). Chemosphere 64:1675-1683

Costello AM, Auman AJ, Macalady JL, Scow KM, Lidstrom ME (2002) Estimation of methanotroph abundance in a freshwater lake sediment. Environ Microbiol 4:443-450

Cotner JB, Biddanda BA (2002) Small players, large role: microbial influence on biogeochemical processes in pelagic aquatic ecosystems. Ecosystems 5:105-121

D'Hondt SL, Rutherford S, Spivack AJ (2002) Metabolic activity of subsurface life in deep-sea sediments. Science 295:2067-2070

Denich TJ, Beaudette LA, Lee H, Trevors JT (2003) Effect of selected environmental and physico-chemical factors on bacterial cytoplasmic membranes. J Microbiol Meth 52:149-182

Dias ACF, Andreote FD, Andreote FD, Lacava PT, Sà ALB, Melo IS, Azevedo JL, Araùjo WL (2009) Diversity and biotechnological 
potential of culturable bacteria from Brazilian mangrove sediment. World J Microbiol Biotechnol 25:1305-1311

Dickson L, Bull ID, Gates PJ, Evershed RP (2009) A simple modification of a silicic acid lipid fractionation protocol to eliminate free fatty acids from glycolipid and phospholipid fractions. J Microbiol Meth 78:249-254

Dijkman NA, Boschker HTS, Stal LJ, Kromkamp JC (2010) Composition and heterogeneity of the microbial community in coastal microbial mat as revealed by the analysis of pigments and phospholipid-derived fatty acids. J Sea Res 63:62-70

Ding H, Valentine DL (2008) Methanotrophic bacteria occupy benthic microbial mats in shallow marine hydrocarbon seeps, Coal Oil Point, California. J Geophys Res 113:1-11

Dong H, Zhang G, Jiang H, Yu B, Chapman LR, Lucas CR, Fields MW (2006) Microbial diversity in sediments of saline Qinghai Lake, China: linking geochemical controls to microbial ecology. Microb Ecol 51:65-82

Dowhan W, Bogdanov M (2002) Functional roles of lipids in membranes. In: Vance DE, Vance JE (eds) Biochemistry of lipids, lipoproteins and membranes, 4th edn. Elsevier, Amsterdam, pp 1-35

Druffel ERM, Zhang D, Xu X, Ziolkowski LA, Southon JR, dos Santos GM, Trumbore SE (2010) Compound-specific radiocarbon analyses of phospholipid fatty acids and $n$-alkanes in ocean sediments. Radiocarbon 52:1215-1223

Duffy JE, Stachowicz JJ (2006) Why biodiversity is important to oceanography: potential roles of genetic, species, and trophic diversity in pelagic ecosystem processes. Mar Ecol Prog Ser 311:179-189

Elvert M, Boetius A, Knittel K, Jørgensen BB (2003) Characterization of specific membrane fatty acids as chemotaxonomic markers for sulfate-reducing bacteria involved in anaerobic oxidation of methane. Geomicrobiol J 20:403-419

Ertefai TF, Fisher MC, Fredricks HF, Lipp JS, Pearson A, Birgel D, Udert KM, Cavanaugh CM, Gschwend PM, Hinrichs KU (2008) Vertical distribution of microbial lipids and functional genes in chemically distinct layers of a highly polluted meromictic lake. Org Geochem 39:1572-1588

Espinosa LF, Pantoja S, Pinto LA, Rullkötter J (2009) Water column distribution of phospholipid-derived fatty acids of marine microorganisms in the Humboldt Current system off northern Chile. Deep Sea Res II 56:1063-1072

Falkowski PG, Fenchel T, Delong EF (2008) The microbial engines that drive Earth's biogeochemical cycles. Science 320:1034-1039

Findlay RH (1996) The use of phospholipid fatty acid to determine microbial community structure. In: Akkermans ADL, van Elsas JD, de Bruijn FJ (eds) Molecular microbial ecology manual. Kluwer Academic Publishers, Dordrecht, pp 1-18

Fonseca AC, Summers RS, Hernandez MT (2001) Comparative measurements of microbial activity in drinking water biofilters. Water Res 35:3817-3824

Frostegård A, Bååth E (1996) The use of phospholipid analysis to estimate bacterial and fungal biomass in soil. Biol Fertil Soils 22:59-65

Frostegård A, Tunlid A, Bååth E (1993) Phospholipid fatty acid composition, biomass, and activity of microbial communities from two soil types experimentally exposed to different heavy metals. Appl Environ Microbiol 59:3605-3617

Green CT, Scow KM (2000) Analysis of phospholipid fatty acids (PLFA) to characterize microbial communities in aquifers. Hydrogeol J 8:126-141

Harji RR, Bhosie NB, Garg A, Sawant SS, Venkat K (2010) Sources of organic matter and microbial community structure in the sediments of the Visakhapatnam harbor, east coast of Ind. Chem Geol 276:309-317
Hedges JI, Keil RG, Benner R (1997) What happens to terrestrial organic matter in the ocean? Org Geochem 27:195-212

Holmer M, Duarte CM, Boschker HTS, Barrón C (2004) Carbon cycling and bacterial carbon sources in pristine and impacted Mediterranean seagrass sediments. Aquat Microb Ecol 36:227-237

Hu J, Zhang H, Peng P (2006) Fatty acid composition of surface sediments in the subtropical Pearl River estuary and adjacent shelf, Southern China. Estuar Coast Shelf Sci 66:346-356

Inagaki F, Nanoura T, Nakagawa S, Teske A, Lever MA, Lauer A, Suzuki M, Takai K, Delwiche M, Colwell FS, Nealson, Horikoshi K, D’Hondt S, Jøgensen BB (2006) Biogeographical distribution and diversity of microbes in methane hydratebearing deep marine sediments on the Pacific Ocean Margin. Proc Natl Acad Sci USA 103:2815-2820

Kaštovská K, Stibal M, Šabacká M, Černá B, Šantrůčková H, Elster J (2007) Microbial community structure and ecology of subglacial sediments in two polythermal Svalbard glaciers characterized by epifluorescence microscopy and PLFA. Polar Biol 30:277-287

Kaur A, Chaudhary A, Kaur A, Choudhary R, Kaushik R (2005) Phospholipid fatty acid: a bioindicator of environment monitoring and assessment in soil ecosystem. Curr Sci 89:1103-1112

Kennedy AC (1994) Carbon utilization and fatty acid profiles for characterization of bacteria. In: Weaver RW, Angle JS (eds) Methods of soil analysis. Part 2: microbiological and biochemical properties. Soil Science Society of America, Madison, WI, pp 543-556

Kluijver A, Yu J, Houtekamer M, Middelburg JJ, Liu Z (2012) Cyanobacteria as a carbon source for zooplankton in eutrophic Lake Taihu, China, measured by ${ }^{13} \mathrm{C}$ labeling and fatty acid biomarkers. Limnol Oceanogr 57:1245-1254

Knief C, Altendorf K, Lipski A (2003) Linking autotrophic activity in environmental samples with specific bacterial taxa by detection of ${ }^{13}$ C-labelled fatty acids. Environ Microbiol 5:1155-1167

Langworthy DE, Stapleton RD, Sayer GS, Findlay RH (2002) Lipid analysis of the response of a sedimentary microbial community to polycyclic aromatic hydrocarbons. Microb Ecol 43:189-198

Li YL, Peacock AD, White DC, Geyer R, Zhang CL (2007) Spatial patterns of bacterial signature biomarkers in marine sediments of the Gulf of Mexico. Chem Geol 238:168-179

Lipp JS, Hinrichs KU (2009) Structural diversity and fate of intact polar lipids in marine sediments. Geochim Cosmochim Acta 73:6816-6833

Lipp JS, Morono Y, Inagaki F, Hinrichs KU (2008) Significant contribution of Archaea to extant biomass in marine subsurface sediments. Nature 454:991-994

Lombard J, Lopez-Garcia P, Moreira D (2012) Phylogenomic investigation of phospholipid synthesis in Archaea. Archaea. doi: $10.1155 / 2012 / 630910$

Mancuso CA, Franzmann 1D, Burton HR, Nichols PD (1990) Microbial community structure and biomass estimates of a methanogenic Antarctic Lake ecosystem as determined by phospholipid analyses. Microb Ecol 19:73-95

Männistö MK, Salkinoja-Salonen MS, Puhakka JA (2001) In situ polychlorophenol bioremediation potential of the indigenous bacterial community of boreal groundwater. Water Res 35:2496-2504

Mills CT, Amano Y, Slater GF, Dias RF, Iwatsuki T, Mandernack KW (2010) Microbial carbon cycling in oligotrophic regional aquifer near the Tono Uranium Mine, Japan as inferred from $\delta^{13} \mathrm{C}$ and $\Delta^{14} \mathrm{C}$ values of in situ phospholipid fatty acids and carbon sources. Geochim Cosmochim Acta 74:3785-3805

Molari M, Giovannelli D, d'Errico G, Manini E (2012) Factors influencing prokaryotic community structure composition in subsurface coastal sediments. Estuar Coast Shelf Sci 97:141-148

Morgan JAW, Winstanley C (1997) Microbial biomarkers. In: van Elsas JD, Trevors JT, Wellington EMH (eds) Modern soil microbiology. Marcel Dekker Inc, New York, pp 331-348 
Nichols P, Stulp BK, Jones JG, White DC (1986) Comparison of fatty acid content and DNA homology of the filamentous gliding bacteria Vitreoscilla, Flexibacter, Filibacter. Arch Microbiol 146:1-6

Olsson PA (1999) Signature fatty acids provide tools for determination of the distribution and interactions of mycorrhizal fungi in soil. FEMS Microbiol Ecol 29:303-310

Osburn MR, Sessions AL, Pepe-Ranney C, Spear JR (2011) Hydrogen-isotopic variability in fatty acids from Yellowstone National Park hot spring microbial communities. Geochim Cosmochim Acta 75:4830-4845

Pace ML, Carpenter SR, Cole JJ, Coloso JJ, Kitchell JF, Hodgson JR, Middelburg JJ, Preston ND, Solomon CT, Weidel BC (2007) Does terrestrial organic carbon subsidize the planktonic food web in a clear-water lake? Limnol Oceanogr 52:2177-2189

Parkes RJ, Cragg BA, Bale SJ, Getliff JM, Goodman K, Rochelle PA, Fry JC, Weightman AJ, Harvey SM (1994) Deep bacterial biosphere in Pacific Ocean sediments. Nature 371:410-413

Poerschmann J, Koschorreck M, Górecki T (2012) Organic matter in sediments of an acidic mining lake as assessed by lipids analysis. Part I: fatty acids. Sci Total Environ 414:614-623

Popendorf KJ, Lomas MW, van Mooy BAS (2011) Microbial sources of intact polar diacylglycerolipids in the Western North Atlantic Ocean. Org Geochem 42:803-811

Pratt B, Riesen R, Johnston CG (2012) PLFA analyses of microbial communities associated with PAH-contaminated riverbank sediment. Microb Ecol 64:680-691

Rajendran N, Matsuda O, Imamura N, Urushigawa Y (1992) Variation in microbial biomass and community structure in sediments of eutrophic bays as determined by phospholipid ester-linked fatty acids. Appl Environ Microbiol 58:562-571

Ranneklev SB, Bååth E (2003) Use of phospholipid fatty acids to detect previous self-heating events in stored peat. Appl Environ Microbiol 69:3532-3539

Saenz JP, Hopmans EC, Rogers D, Henderson PB, Charette MA, Schouten S, Casciotti KL, Damste JS, Eglinton TI (2012) Distribution of anaerobic ammonia-oxidizing bacteria in a subterranean estuary. Mar Chem 136-137:7-13

Salomonová S, Lamačová J, Rulik M, Rolčik J, Čap L, Bednár P, Barták P (2003) Determination of phospholipid fatty acids in sediments. Chemica 42:39-49

Scherf AN, Rullkötter J (2009) Biogeochemistry of high salinity microbial mats-part 1: lipid composition of microbial mats across intertidal flats of Abu Dhabi, United Arab Emirates. Org Geochem 40:1018-1028

Schoug Å, Fischer J, Heipieper HJ, Schnürer J, Håkansson S (2008) Impact of fermentation $\mathrm{pH}$ and temperature on freeze-drying survival and membrane lipid composition of Lactobacillus coryniformis Si3. J Ind Microbiol Biot 35:175-181

Schulze-Makuch D (2002) Evidence for the discharge of hydrothermal water into Lake Lucero, White Sands National Monument, Southern New Mexico. New Mexico Geological Society Guide Book. In: 53rd field conference, geology of white sands, pp 325-329

Slater GF, Cowie BR, Harper N, Droppo IG (2008) Variation in PAH inputs and microbial community in surface sediments of Hamilton Harbour: implications to remediation and monitoring. Environ Pollut 153:60-70

Stoeck T, Kröncke I, Duineveld GCA, Palojärvi A (2002) Phospholipid fatty acid profiles at depositional and non-depositional sites in the North Sea. Mar Ecol Prog Ser 241:57-70

Stolz J (2000) Structure of microbial mats and biofilms. In: Riding RE, Awramik SM (eds) Microbial sediments. Springer, Berlin, pp 1-8

Sundh I, Bastviken D, Tranvik LJ (2005) Abundance, activity, and community structure of pelagic methane-oxidizing bacteria in temperate lakes. Appl Environ Microbiol 71:6746-6752
Taipale S, Jones RI, Tiirola M (2009) Vertical diversity of bacteria in an oxygen-stratified humic lake, evaluated using DNA and phospholipid analyses. Aquat Microb Ecol 55:1-16

Tolosa I, LeBlond N, Montegut CC, Marty C, deMora S, Prieur L (2003) Distribution of sterol and fatty alcohol biomarkers in particulate matter from the frontal structure of the Alboran Sea. Mar Chem 82:161-183

van den Meersche K, Van Rijswijk P, Soetaert K, Middelburg JJ (2009) Autochthonous and allochthonous contributions to mesozooplankton diet in a tidal river and estuary: integrating carbon isotope and fatty acid constraints. Limnol Oceanogr 54:62-74

Varadhan AS, Khodadoust AP, Brenner R (2011) Effect of biostimulation on the microbial community in PCB-contaminated sediments through periodic amendment of sediment with iron. Ind Microbiol Biotechnol 38:1691-1707

Villanueva L, Navarrete A, Urmeneta J, White DC, Guerrero R (2007) Analysis of diurnal and vertical microbial diversity of a hypersaline microbial mat. Arch Microbiol 188:137-146

Wakeham SG, McNichol AP, Kostka JE, Pease TK (2006) Naturalabundance radiocarbon as a tracer of assimilation of petroleum carbon by bacteria in salt marsh sediments. Geochim Cosmochim Acta 70:1761-1771

Webster G, Watt LC, Rinna J, Fry JC, Evershed RP, Parkes RJ, Welghtman AJ (2006) A comparison of stable-isotope probing of DNA and phospholipid fatty acids to study prokaryotic functional diversity in sulfate-reducing marine sediment enrichment slurries. Environ Microbiol 8:1575-1589

White DC (1983) Analysis of microorganisms in terms of quantity and activity in natural environments. In: Slater JH, Whittenbury $\mathrm{R}$, Wimpenny JWT (eds) Microbes in their natural environments. Society of General Microbiology Symposium, vol 34, pp 37-66

White DC, Ringelberg DB (1997) Utility of the signature lipid biomarker analysis in determining in situ viable biomass, community structure and nutritional/physiological status of deep subsurface microbiota. In: Amy PS, Haldeman D (eds) The microbiology of the terrestrial deep subsurface. LCRC Press, New York, pp 119-136

White DC, Pinkard HC, Ringelberg DB (1997) Biomass measurements: biochemical approaches. In: Hurst CJ, Knudsen GR, Mc Inerney MJ, Stetzenbach LD, Valter MV (eds) Manual of environmental microbiology. ASM Press, Washington, pp 91-101

Whitman WB, Coleman DC, Wiebe WJ (1998) Prokaryotes: the unseen majority. Proc Natl Acad Sci USA 95:6578-6583

Widenfalk A, Bertilsson S, Sundh I, Goedkoop W (2008) Effect of pesticides on community composition and activity of sediment microbes-responses at various levels of microbial community organization. Environ Pollut 152:576-584

Yu X, Shi X, Wei B, Ye L, Zhang S (2009) PLFA profiles of drinking water biofilters with different acetate and glucose loadings. Ecotoxicology 18:700-706

Zelles L, Bai QY, Ma RX, Rackwitz R, Winter K, Beese F (1994) Microbial biomass, metabolic activity and nutritional status determined from fatty acid patterns and polyhydroxybutyrate in agriculturally-managed soils. Soil Biol Biochem 26:439-446

Zhang CL, Huang Z, Cantu J, Pancost RD, Brigmon RL, Lyons TW, Sassen R (2005) Lipid biomarkers and carbon isotope signatures of a microbial (Beggiatoa) mat associated with gas hydrates in the Gulf of Mexico. Appl Environ Microbiol 71:2106-2112

Zhukova NV (2005) Variation in microbial biomass and community structure in sediments of Peter the Great Bay (Sea of Japan/East Sea), as estimated from fatty acid biomarkers. Ocean Sci J 40:1-9

Zinger L, Gobet A, Pommier T (2012) Two decades of describing the unseen majority of aquatic microbial diversity. Mol Ecol 21:1878-1896 